\title{
Dietary zinc deficiency predisposes mice to the development of preneoplastic lesions in chemically-induced hepatocarcinogenesis
}

\author{
Guilherme Ribeiro Romualdo a, Renata Leme Goto ${ }^{b}$, Ana Angélica Henrique Fernandes ${ }^{\text {c }}$, \\ Bruno Cogliati ${ }^{\mathrm{d}}$, Luis Fernando Barbisan ${ }^{\mathrm{b}, *}$ \\ ${ }^{a}$ UNESP - São Paulo State University, Botucatu Medical School, Department of Pathology, Botucatu, São Paulo State, Brazil

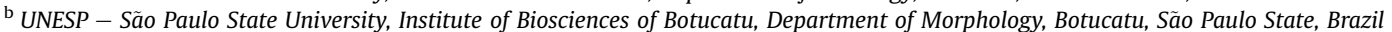 \\ ${ }^{c}$ UNESP - São Paulo State University, Institute of Biosciences of Botucatu, Department of Chemistry and Biochemistry, Botucatu, São Paulo State, Brazil \\ ${ }^{\mathrm{d}}$ USP - University of São Paulo, School of Veterinary Medicine and Animal Science, Department of Pathology, São Paulo, São Paulo State, Brazil
}

\section{A R T I C L E I N F O}

\section{Article history:}

Received 19 July 2016

Received in revised form

10 August 2016

Accepted 16 August 2016

Available online 17 August 2016

\section{Keywords:}

Antioxidant defense

Diethylnitrosamine

Mouse hepatocarcinogenesis

Preneoplasia

Zinc deficiency

Zinc supplementation

\begin{abstract}
A B S T R A C T
Although there is a concomitance of zinc deficiency and high incidence/mortality for hepatocellular carcinoma in certain human populations, there are no experimental studies investigating the modifying effects of zinc on hepatocarcinogenesis. Thus, we evaluated whether dietary zinc deficiency or supplementation alter the development of hepatocellular preneoplastic lesions (PNL). Therefore, neonatal male Balb/C mice were submitted to a diethylnitrosamine/2-acetylaminefluorene-induced hepatocarcinogenesis model. Moreover, mice were fed adequate $(35 \mathrm{mg} / \mathrm{kg}$ diet $)$, deficient ( $3 \mathrm{mg} / \mathrm{kg}$ ) or supplemented $(180 \mathrm{mg} / \mathrm{kg}$ ) zinc diets. Mice were euthanized at 12 (early time-point) or 24 weeks (late time-point) after introducing the diets. At the early time-point, zinc deficiency decreased Nrf2 protein expression and GSH levels while increased p65 and p53 protein expression and the number of PNL/area. At the late timepoint, zinc deficiency also decreased GSH levels while increased liver genotoxicity, cell proliferation into PNL and PNL size. In contrast, zinc supplementation increased antioxidant defense at both timepoints but not altered PNL development. Our findings are the first to suggest that zinc deficiency predisposes mice to the PNL development in chemically-induced hepatocarcinogenesis. The decrease of $\mathrm{Nrf2/GSH}$ pathway and increase of liver genotoxicity, as well as the increase of p65/cell proliferation, are potential mechanisms to this zinc deficiency-mediated effect.
\end{abstract}

(3) 2016 Elsevier Ltd. All rights reserved.

\section{Introduction}

Zinc, an important trace element, is required as a cofactor for approximately $10 \%$ of total proteins encoded by the human genome, including enzymes $(>200)$ and transcription factors $(>3000)$ related to basic cellular functions as proper antioxidant defense, immune response, DNA repair and cell proliferation (Andreini et al., 2006; Roohani et al., 2013). According to the US Food and Nutrition Board (2001), the human Recommended Dietary Allowance (RDA) for zinc is 11 and $8 \mathrm{mg} /$ day for adult men and women, respectively. Animal products, mainly sea food and red meat, are the most important dietary sources of readily bioavailable

\footnotetext{
* Corresponding author. Departamento de Morfologia, Instituto de Biociências, Universidade Estadual Paulista (UNESP), Rua Prof. Dr. Antonio Celso Wagner Zanin s/n, 18618-689, Botucatu, SP, Brazil.
}

E-mail address: barbisan@ibb.unesp.br (L.F. Barbisan). zinc while plant products are considered poor ones (Ma and Betts, 2000).

An estimated $17.3 \%$ of the human population is at risk of inadequate zinc intake and subsequent zinc deficiency, mainly in SubSaharan Africa and South Asia (Wessells and Brown, 2012). Experimentally, dietary zinc deficiency showed to induce and/or promote chemically-induced esophagus, tongue and colon rodent carcinogenesis (Alder et al., 2012; Christudoss et al., 2012; Fong et al., 2006; Taccioli et al., 2012). In addition, a recent meta-analysis revealed decreased zinc levels in serum and tumor tissue of patients with lung, head and neck, liver, stomach, prostate and thyroid malignant neoplasms (Gumulec et al., 2014). These experimental and human studies indicate a possible underlying role of zinc deficiency on carcinogenesis process. In contrast, zinc supplementation, usually applied to reverse and/or prevent zinc deficiency on human populations (Brooks et al., 2005; Yakoob et al., 2011), showed to inhibit or attenuate chemically-induced colon, forestomach, oral and prostate rodent carcinogenesis (Banudevi et al., 2011; Dani et al., 
2007; Fong et al., 2011; Sun et al., 2011). Furthermore, zinc supplementation augmented the antitumor effect of adriamycin chemotherapy in MMTV-neu transgenic mouse model of mammary carcinogenesis (Margalit et al., 2012). These in vivo studies also suggest a possible role of zinc supplementation on cancer prevention and treatment. In spite of these findings, there are no experimental studies that investigated the modifying effects of zinc deficiency or supplementation on hepatocarcinogenesis.

The Hepatocellular Carcinoma (HCC) is the sixth most common cancer and the second cause of cancer-related deaths worldwide (GLOBOCAN, 2012). The highest incidence and mortality rates due to this malignant neoplasm are found in Asia and Africa (GLOBOCAN, 2012). HCC development is considered a complex, multistep and multifactorial process, involving several risk factors, including chronic hepatitis B and C virus infections, aflatoxin and chronic ethanol intake and non-alcoholic fatty liver disease (NAFLD) (Sanyal et al., 2010).

Mouse models of hepatocarcinogenesis are widely applied in translational research due to morphological and molecular similarities to human HCC (Zucman-Rossi, 2008; Bakiri and Wagner, 2013). Particularly, chemically-induced models provide suitable tools to study several aspects of hepatocarcinogenesis, including risk factors, molecular pathogenesis, prevention and treatment (Bakiri and Wagner, 2013). Diethylnitrosamine (DEN) and 2acetylaminefluorene (2-AAF) are classical mutagenic/genotoxic agents applied in initiation-promotion models of hepatocarcinogenesis (Park et al., 2011; Santos et al., 2014). Both agents undergo liver metabolism by cytochrome P450 (Jin et al., 2007; Liu et al., 2005), resulting in reactive oxygen species (ROS) and nucleophilic ions, which induce DNA damage and implicate in genomic instability, mutation and ultimately, contribute to the development of hepatocellular preneoplastic and neoplastic lesions (Kraynak et al., 2015; Santos et al., 2014). Notably, the neonatal mouse model of hepatocarcinogenesis is usually established due to the intrinsic susceptibility of neonatal liver to chemical carcinogen exposure, particularly to DEN (Vesselinovitch et al., 1984; Vesselinovitch, 1987). Besides, high cell proliferation rates in the liver of juvenile mice may favor the clonal expansion of initiated hepatocytes, resulting in earlier occurrence of preneoplastic and neoplastic lesions compared to chemically-induced adult mouse models (Vesselinovitch et al., 1984; Vesselinovitch, 1987). In these short- or medium-term bioassays, altered hepatocyte foci (AHF) have been used as putative preneoplastic lesions (PNL) (Pitot, 1990). AHF can be easily identified in liver sections stained by hematoxilin and eosin (HE), which enables the screening of potential causative or preventive factors on early hepatocarcinogenesis, including specific dietary factors (Palmeira et al., 2015; Pitot, 1990), as zinc.

Although there is a concomitance of zinc deficiency and high incidence/mortality for HCC in certain human populations, literature lacks on experimental studies on the modifying effects of zinc deficiency or supplementation on hepatocarcinogenesis process. Thus, we are the first to evaluate whether dietary zinc deficiency or supplementation alter the PNL development in chemically-induced mouse hepatocarcinogenesis.

\section{Materials and methods}

\subsection{Experimental design}

Pregnant Balb/C mice were obtained from Multidisciplinary Center for Biological Investigation on Laboratory Animal Science (CEMIB, UNICAMP, Campinas - SP, Brazil). Neonatal male mice were submitted to a classical hepatocarcinogenesis model by receiving a single intraperitoneal (i.p.) injection of DEN $[50 \mathrm{mg} / \mathrm{kg}$ body weight (b.wt.) in $0.9 \%$ saline, Sigma-Aldrich, USA] at postnatal day 15 (PND 15) (Klaunig et al., 1988) (Fig. 1). At PND 28, the mice were randomly allocated into three groups ( $\mathrm{n}=13$ mice each). They were fed AIN-93G semipurified diet (Reeves et al., 1993) containing different concentrations of elemental zinc ( $\mathrm{Zn}$ ) by adding zinc sulphate salt: groups receiving adequate zinc diet (GZnA, $35 \mathrm{mg} / \mathrm{kg}$ diet), dietary zinc deficiency (GZnD, $3 \mathrm{mg} / \mathrm{kg}$ diet) or dietary zinc supplementation (GZnS, $180 \mathrm{mg} / \mathrm{kg}$ diet) (Fig. 1). Also, 2-AAF (Sigma-Aldrich, USA) was incorporated at $0.02 \%$ in all experimental diets (Bitsch et al., 2000) (Fig. 1). The animals were euthanized by exsanguination under ketamine/xylazine anesthesia (100/ $16 \mathrm{mg} / \mathrm{kg}$ b.wt., i.p.) at 12 ( $\mathrm{n}=6 \mathrm{mice} /$ group) or 24 weeks $(\mathrm{n}=7$ mice/group) after introducing experimental diets (Fig. 1). These endpoints were established in order to evaluate the effects of zinc deficiency or supplementation on early (12 weeks) and late (24 weeks) time-points of hepatocellular PNL development.

Peripheral blood samples were collected from the venous orbital plexus one day before euthanasia to perform Comet Assay for DNA damage analysis. Blood samples were collected by cardiac puncture and serum samples were stored at $-20{ }^{\circ} \mathrm{C}$ to further determine Alanine Aminotransferase (ALT) levels. At necropsy, the liver was removed, weighed, washed in saline solution $(0.9 \% \mathrm{NaCl})$ and representative samples from all lobes were collected and processed for histopathological and immunohistochemical analysis. Additional liver samples were collected, snap-frozen in liquid nitrogen and stored at $-80{ }^{\circ} \mathrm{C}$ to further performance of Comet Assay, western blot, antioxidant profiling and zinc level determination. The animals were kept in a room with ventilation (16-18 air changes/hour), relative humidity (45-65\%), controlled temperature $\left(20-24{ }^{\circ} \mathrm{C}\right)$ and light/dark cycle $12: 12$ and were given deionized water and diet ad libitum. Body weight and food consumption were recorded twice a week during the experimental period. The animal experiment was carried out under protocols approved by Botucatu Medical School/UNESP Ethics Committee on Use of Animals (CEUA) (Protocol number 1073/14) and all animals received humane care according to the criteria outlined in the "Guide for the Care and Use of Laboratory Animals" (2011).

\subsection{Diets}

Adequate zinc diet was designed to meet the recommended dietary zinc intake for mice (National Academy of Sciences , 2001). Zinc deficient diet was designed to contain $~ 10$-fold lower zinc than adequate diet and to induce low zinc status, similarly to human dietary zinc deficiency, as previously established in chemicallyinduced carcinogenesis bioassays (Lee et al., 2004; Alder et al., 2012). In contrast, the zinc supplemented diet was produced to contain $\sim 5$-fold higher zinc than adequate diet, similarly to rodent studies and usually applied human zinc supplementation regimens (Ko et al., 2005; Huang et al., 2007). Samples of each AIN-93G diet formulation (in triplicate) were submitted to flameless atomic absorption spectroscopy (AAS) analysis (see item 2.7), confirming zinc levels in the experimental diets before introducing them to the mice (adequate zinc: $34.30 \pm 4.60$; zinc deficiency: $3.40 \pm 0.30$; zinc supplementation: $174.50 \pm 15.80$, in $\mathrm{mg} \mathrm{Zn} / \mathrm{Kg}$ diet, values are Mean \pm S.D.).

\subsection{Histopathological evaluation}

Liver samples were fixed in $10 \%$ buffered formalin for $24 \mathrm{~h}$ at room temperature, stored in $70 \%$ ethanol and embedded in paraffin. Five-micron thick liver sections were stained with hematoxilin and eosin (HE). AHF were identified using previously well-established morphological criteria (Thoolen et al., 2010). The incidence of these lesions was calculated for each group. Besides, we also calculated AHF number/liver area, by counting all AHF and dividing 




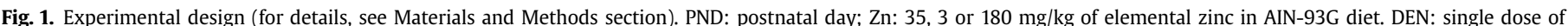

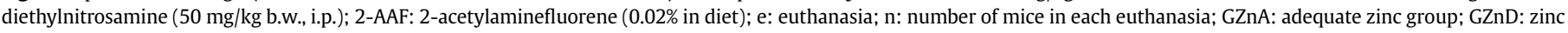
deficiency group; GZnS: zinc supplementation group.

by the liver section area analyzed, and AHF size, by individually measuring all AHF. Each liver section area $\left(\mathrm{cm}^{2}\right)$ and AHF size $\left(\mathrm{mm}^{2}\right)$ were measured using KS300 image analysis system (Carl Zeiss, Germany).

\subsection{Immunohistochemistry and semi-quantitative analysis}

Immunoreactivity for Ki-67 and $\beta$-catenin was detected using a universal labeled streptavidin-biotin system (LSAB System-HRP, Dako Cytomation, Denmark). Briefly, deparaffinated 5- $\mu$ m liver sections on silanized slides were treated sequentially with citrate buffer $\left(120^{\circ} \mathrm{C}, 5 \mathrm{~min}\right)$ in a Pascal Pressure Chamber (Dako Cytomation, Denmark), $3 \% \mathrm{H}_{2} \mathrm{O}_{2}$ in phosphate-buffered saline (PBS) (10 min), nonfat milk (60 min), anti-Ki-67 (ab16667, 1:100 dilution, Abcam, UK) or $\beta$-catenin (ab32572, 1:400 dilution, Abcam, UK) antibodies overnight $\left(4^{\circ} \mathrm{C}\right)$, followed by biotinylated universal link and streptavidin HPR (20 min each) solutions. Chromogen color development was accomplished with 3,3'-diaminobenzidine tetrahydrochroride (Sigma-Aldrich, USA). The slides were counterstained with Harris's hematoxylin for $1 \mathrm{~min}$. For Ki-67 semiquantitative analysis in normal-appearing liver tissue, 40 random fields ( $40 \times$ objective) were assessed in sections comprising all liver lobes. Ki-67-positive hepatocytes were counted and divided by the liver area analyzed $\left(\mathrm{mm}^{2}\right)$. In AHF, Ki-67-positive hepatocytes were counted and divided by AHF area $\left(\mathrm{mm}^{2}\right)$. For $\beta$-catenin, only the pattern of staining was evaluated (membranous, cytoplasmic and/ or nuclear) in normal-appearing liver and into AHF. All analyses were performed in an Olympus CellSens software (Olympus Corporation, Japan).

\subsection{Comet Assay}

Comet Assay was performed on peripheral blood and liver samples by following the well-established protocol proposed by Tice et al. (2000). Peripheral blood samples were collected from the venous orbital plexus one day before euthanasia. Liver samples from the left lobe $(\sim 50 \mathrm{mg})$ were gently minced in ice-cold $\mathrm{Ca}^{2+}$ and $\mathrm{Mg}^{2+}$ free PBS solution to obtain cell suspensions. Peripheral blood $(5 \mu \mathrm{L})$ or liver cell suspension $(20 \mu \mathrm{L})$ were mixed with $100-140 \mu \mathrm{L}$ low melting point agarose (Invitrogen, USA) dissolved in $\mathrm{Ca}^{2+}$ and $\mathrm{Mg}^{2+}$ free PBS. The mixture was spread onto microscope slides precoated with normal melting point agarose (Invitrogen, USA). The slides were covered with a coverslip and maintained at $4{ }^{\circ} \mathrm{C}$
(5 min). Then, the coverslip was removed and slides were immersed in cold, freshly prepared, lysis solution containing $2.5 \mathrm{M}$ $\mathrm{NaCl}, 100$ mM EDTA, $10 \mathrm{mM}$ Tris, 1\% N-lauroyl-sarcosine, 1\% Triton $\mathrm{X}-100$ and 10\% DMSO (all reagents from Sigma-Aldrich, USA) $\left(4^{\circ} \mathrm{C}\right.$, $60 \mathrm{~min}$ ). After lysis, prior to electrophoresis, slides were placed in a horizontal electrophoresis unit and left in alkaline buffer containing $0.3 \mathrm{mM} \mathrm{NaOH}$ and $1 \mathrm{mM}$ EDTA ( $\mathrm{pH}>13,20 \mathrm{~min}$ ) and electrophoresed $30 \mathrm{~V}(0.86 \mathrm{~V} / \mathrm{cm})$ and $300 \mathrm{~mA}(20 \mathrm{~min})$. Finally, the slides were neutralized in $0.4 \mathrm{M}$ Tris- $\mathrm{HCl}(\mathrm{pH} 7.5)$, fixed in absolute ethanol and stored at room temperature until blind analysis in a fluorescence microscope (Olympus, Japan) at $20 \times$ magnification. Each slide was stained with $80 \mu \mathrm{L}$ of SYBR $^{\circledR}$ Gold Stain solution (1:10.000, Life Technologies, USA) and immediately analyzed. To minimize extraneous DNA damage from ambient ultraviolet radiation, all steps were performed with reduced illumination. Genotoxicity analysis was performed in Comet Assay IV (Perceptive Instruments, UK). Tail intensity (percentage of DNA in the comet tail) was used as a reliable parameter to evaluate DNA damage in 50 nucleoids per slide/two slides per animal (Kumaravel and Jha, 2006).

\subsection{Hepatic antioxidant profiling and serum ALT}

Liver samples were homogenized in $50 \mathrm{mM}$ phosphate buffer ( $\mathrm{pH}$ 7.4) with auxiliary of the motor-driven teflon glass Potter Elvehjem $(100 \times \mathrm{g} / \mathrm{min})$. The tissue homogenate was centrifuged $\left(12000 \times \mathrm{g},-4{ }^{\circ} \mathrm{C}, 15 \mathrm{~min}\right)$. The supernatant was used to determine total protein and reduced glutathione (GSH) levels and to evaluate total superoxide dismutase (SOD), catalase and glutathione peroxidase (GPX) activities. GSH was measured by a kinetic assay in reaction medium containing $2 \mathrm{mM}$ 5,5'-DTNB acid, $0.2 \mathrm{mM} \mathrm{NADPH}$ and $2 \mathrm{U}$ of glutathione reductase (Sigma-Aldrich, USA) in phosphate buffer (Sedlak and Lindsay, 1968). SOD activity was determined based on the ability of the enzyme to inhibit the reduction of nitro blue tetrazolium (NBT), which was generated by hydroxylamine in a medium containing phosphate buffer, $0.1 \mathrm{mM}$ EDTA, $50 \mu \mathrm{M}$ NTB, $78 \mu \mathrm{M}$ NADH and $33 \mu \mathrm{M}$ phenazine methosulfate (Ewing and Janero, 1995). Catalase activity was determined in a mixture containing $10 \mathrm{mM}$ hydrogen peroxide and sodium phosphate buffer $50 \mathrm{mM}$, pH 7.0, in a final volume of $0.3 \mathrm{~mL}$ (Bergmeyer, 1974). GPx activity was assayed by following the oxidation of $0.16 \mathrm{mM}$ NADPH in the presence of glutathione reductase which catalyzed the reduction of GSSG formed by the GPx (Nakamura et al., 1974). 
Finally, serum ALT levels were determined by a conventional kinetic assay according to the manufacturer's instructions (Liquiform - Labtest Diagnóstica, Brazil). All determinations were performed using a microplate reader $\left(25^{\circ} \mathrm{C}\right)$ ( $\mu$ Quant-Gen5 2.0 software, BioTec Instruments, USA).

\subsection{Zinc determination}

Liver or AIN-93G diet samples were mineralized in a 16-N nitric acid solution by microwave irradiation (Model DGT 100, Provecto, Brazil). Zinc concentration was determined from the mineralized materials by flameless AAS (GBC, Model 932 AA).

\subsection{Western blot}

Liver samples were homogenized in lysis buffer (500 nM Tris$\mathrm{HCl}, 0.2 \mathrm{M} \mathrm{NaCl}, 1 \%$ Triton $\mathrm{X}-100,10 \mathrm{nM} \mathrm{CaCl} 2$, and $2 \mu \mathrm{L} / 100 \mathrm{~mL}$ protease inhibitor cocktail, Sigma-Aldrich, USA) in the proportion of $30 \mathrm{mg}$ of tissue $/ 100 \mu \mathrm{L}$ of buffer $\left(4^{\circ} \mathrm{C}, 2 \mathrm{~h}\right)$. After this procedure, the extracted material was centrifuged $\left(4000 \mathrm{rpm}, 4{ }^{\circ} \mathrm{C}, 20 \mathrm{~min}\right)$ and the supernatant collected for protein quantification by Bradford's method. Aliquots of liver homogenates containing $70 \mu \mathrm{g}$ of total protein were heated $\left(95^{\circ} \mathrm{C}, 5 \mathrm{~min}\right.$ ) in sample-loading buffer and then electrophoretically separated in a 12\% SDS-PAGE gel under reducing conditions and transferred to nitrocellulose membranes (Sigma-Aldrich, USA). Membranes were blocked with nonfat milk in TBS-T (0.05 M Tris, $0.15 \mathrm{M} \mathrm{NaCl}, \mathrm{pH} 7.2,1 \%$ Tween-20) $(1 \mathrm{~h})$. Membranes were subsequently incubated with anti-NFKB p65 (sc-372, 65 KDa, 1:1000 dilution, Santa Cruz Biotechnology, USA), p53 (sc-6243, 53 KDa, 1:500 dilution, Santa Cruz Biotechnology, USA), Nrf2 (ab31163, 68 KDa, 1:1000 dilution, Abcam, UK), $\beta$-Catenin (ab32572, 92-86 KDa, 1:5000 dilution, Abcam, UK) or actin (sc1815, 43 KDa, 1:1000 dilution, Santa Cruz Biotechnology, USA) primary antibodies in 5\% BSA solution overnight. After 5 wash steps with PBS-T, membranes were incubated with specific horseradish conjugated secondary antibodies, according to the primary antibodies used ( $2 \mathrm{~h}$ ). Finally, after 5 wash steps, the membranes were submitted to immunoreactive protein signals detected using the Amersham ECL Select Western Blotting Detection Reagent (GE Healthcare Life Sciences, UK). Signals were captured by a G:BOX Chemi system (Syngene, UK) controlled by an automatic software (GeneSys, Syngene, UK). Band intensities were quantified using densitometry analysis software (Image J software, Austria) and p53, $\mathrm{NF \kappa B}$ (p65), Nrf2 and $\beta$-catenin protein expression was reported as fold change according to actin protein expression, used as a normalizer. For each marker (in each time-point), we ran 2 samples of each group/gel, totalizing 3 gels and 6 samples/group.

\subsection{Statistical analysis}

Data were analyzed by One-Way ANOVA and post hoc Tukey's test. The incidence of histopathological findings was analyzed by Fisher's Exact Test. The differences were considered significant at $\mathrm{p}<0.05$. All statistical analyses were performed using 3.5 Jandel Sigma Stat software (Jandel Corporation, USA).

\section{Results}

\subsection{Zinc deficiency and supplementation do not alter food consumption, liver and body weight}

During the whole experimental period, no death or specific clinical signs were observed. Moreover, final body weight, body weight gain, food intake and relative liver weight (\%) values were similar among the experimental groups at both early (week 12) and
Table 1

Effects of dietary zinc deficiency or supplementation on food consumption, liver and body weights, and hepatic zinc levels at weeks 12 and 24 .

\begin{tabular}{llll}
\hline Period/Parameters & \multicolumn{2}{l}{ Groups $^{\mathrm{a}}$} & \\
\cline { 2 - 4 } & $\mathrm{GZnA}$ & $\mathrm{GZnD}$ & $\mathrm{GZnS}$ \\
\hline PND 28 - Week $12(n=6$ mice/group) & & & \\
$\quad$ Final body weight $(\mathrm{g})$ & $26.7 \pm 1.36$ & $29.6 \pm 1.50$ & $26.6 \pm 1.36$ \\
Body weight gain (g) & $11.6 \pm 2.06$ & $12.6 \pm 2.51$ & $13.0 \pm 1.89$ \\
Liver relative weight (\%) & $4.15 \pm 0.30$ & $4.43 \pm 0.21$ & $4.67 \pm 0.11$ \\
Food consumption (g/mouse/day) & $3.31 \pm 0.16$ & $3.35 \pm 0.43$ & $3.29 \pm 0.30$ \\
Liver Zinc ( $\mu$ g/g tissue) & $25.1 \pm 0.47$ & $24.3 \pm 0.32$ & $26.0 \pm 0.87$ \\
PND 28 - Week 24 $(n=7$ mice/group) & & & \\
Final body weight (g) & $31.0 \pm 2.16$ & $32.8 \pm 4.77$ & $29.8 \pm 0.89$ \\
Body weight gain (g) & $17.0 \pm 3.26$ & $15.0 \pm 4.65$ & $15.0 \pm 2.58$ \\
Liver relative weight (\%) & $4.95 \pm 0.95$ & $4.27 \pm 0.78$ & $4.24 \pm 0.89$ \\
Food consumption (g/mouse/day) & $3.52 \pm 0.32$ & $3.78 \pm 1.33$ & $3.41 \pm 0.31$ \\
Liver Zinc $(\mu \mathrm{g} / \mathrm{g}$ tissue) & $26.8 \pm 1.08$ & $22.5 \pm 1.43^{*}$ & $25.3 \pm 4.75$ \\
\hline
\end{tabular}

Values are Mean \pm S.D.

a GZnA (adequate zinc, $35 \mathrm{mg} / \mathrm{kg}$ diet), GZnD (zinc deficiency, $3 \mathrm{mg} / \mathrm{kg}$ diet) or GZnS (zinc supplementation, $180 \mathrm{mg} / \mathrm{kg}$ diet) from postnatal day 28 until weeks 12 or 24. All mice were submitted to DEN/2-AAF treatment (see Material and Methods section). Asterisks correspond to statistical difference compared to GZnA group by ANOVA post hoc Tukey's test: *p $<0.01$.

late (week 24) time-points (Table 1). Some studies reported decreased appetite and body weight in rats exposed to dietary zinc deficiency (Lee et al., 2004; Song et al., 2009). However, these alterations are not frequently observed in mice, as previously reported by others (Zhong et al., 2013).

\subsection{Zinc deficiency decreases hepatic zinc levels}

In fact, dietary zinc deficiency decreased hepatic zinc levels in comparison to adequate zinc diet at week $24(\mathrm{p}=0.006)$ (Table 1$)$, as previously reported (Alder et al., 2012; Zhong et al., 2013). However, dietary zinc supplementation did not significantly alter hepatic zinc levels. Indeed, increased hepatic zinc concentrations are only observed in higher dietary zinc supplementation regimens (300 mg/kg) (Jing et al., 2015).

\subsection{Zinc deficiency increases the number of AHF/liver area and AHF} size

Histopathological examination revealed PNL showing basophilic, eosinophilic or clear cells (Fig. 2A). The groups did not significantly differ on the incidence of the different types of PNL in both experimental periods (Table 2). However, dietary zinc deficiency increased the number of AHF per liver area at the early (week 12 ) and AHF size at the late time-point (week 24) $(\mathrm{p}=0.004$ and $\mathrm{p}<0.001$, respectively) in comparison to the other groups (Fig. $2 \mathrm{~B}$ and C). ALT serum levels were similar among the experimental groups at week $12(\mathrm{GZnA}: 52.83 \pm 11.14$; GZnD: $59.89 \pm 13.26$; GZnS: $61.63 \pm 9.65$, in $U / L$, values are Mean \pm S.D.) and week 24 (GZnA: $64.57 \pm 14.38$; GZnD: $57.86 \pm 13.31$; GZnS: $59.87 \pm 9.65$, in $\mathrm{U} / \mathrm{L}$, values are Mean \pm S.D.).

\subsection{Zinc deficiency increases cell proliferation into AHF}

Ki-67 immunoreactivity revealed typical nuclear staining in hepatocytes of normal-appearing liver tissue and into AHF (Fig. 3A). AHF containing Ki-67-positive hepatocytes were only observed at the late time-point (week 24). Ki-67 semi-quantitative analysis in normal-appearing liver areas was similar among the experimental groups at both moments (Fig. 3B). Nonetheless, zinc deficiency increased cell proliferation in preneoplastic AHF in comparison to the other groups at week $24(\mathrm{p}=0.016$ ) (Fig. 3B). Lastly, $\beta$-catenin 
(A)
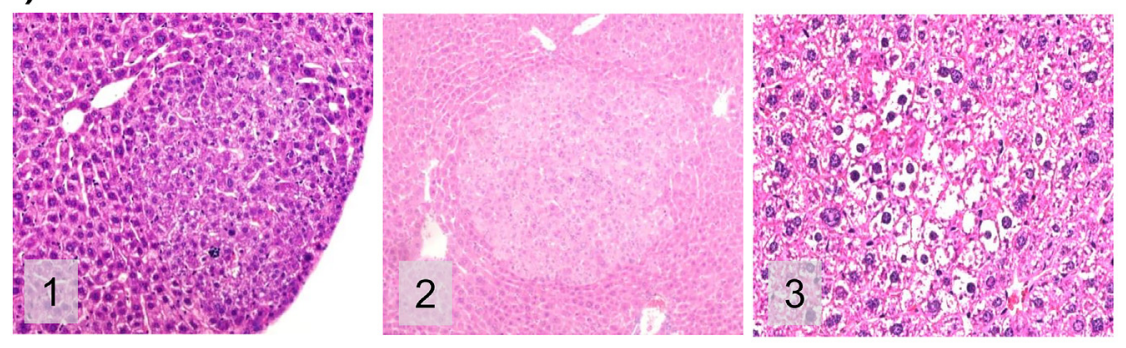

(B)



(C)



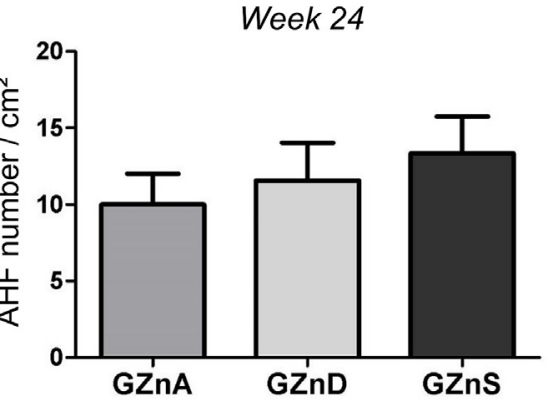

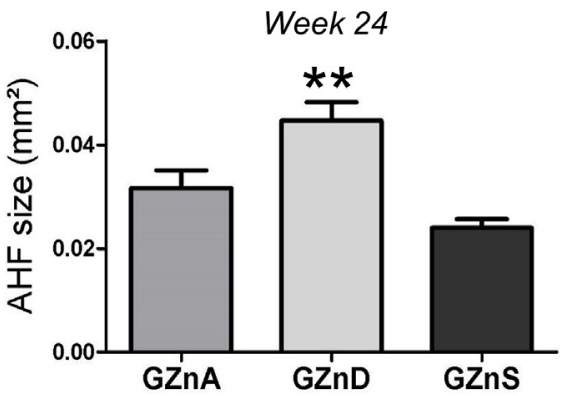



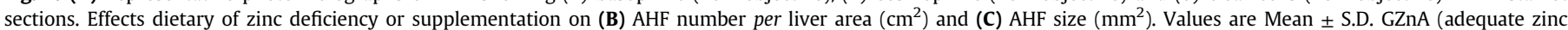



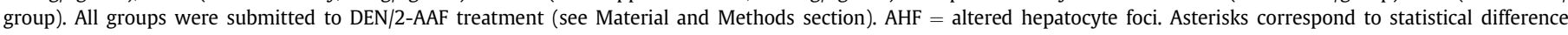
compared to the other groups by ANOVA post hoc Tukey's test: ${ }^{*} \mathrm{p}<0.01$; ${ }^{* *} \mathrm{p}<0.001$.

Table 2

Effects of dietary zinc deficiency or supplementation on the incidence of preneoplastic AHF at weeks 12 and 24.

\begin{tabular}{|c|c|c|c|}
\hline \multirow[t]{2}{*}{ Week/AHF type } & \multicolumn{3}{|l|}{ Groups $^{\mathrm{a}}$} \\
\hline & GZnA & GZnD & GZnS \\
\hline \multicolumn{4}{|c|}{ Week 12 ( $n=6$ mice/group $)$} \\
\hline Basophilic cell foci & $5 / 6(83.3 \%)$ & $6 / 6(100 \%)$ & $6 / 6(100 \%)$ \\
\hline Eosinophilic cell foci & $0 / 6(0)$ & $0 / 6(0)$ & $0 / 6(0)$ \\
\hline Clear cell foci & $0 / 6(0)$ & $0 / 6(0)$ & $0 / 6(0)$ \\
\hline \multicolumn{4}{|c|}{ Week 24 ( $n=7$ mice/group) } \\
\hline Basophilic cell foci & $4 / 7(57.1 \%)$ & $4 / 7(57.1 \%)$ & $4 / 7(57.1 \%)$ \\
\hline Eosinophilic cell foci & 7/7 (100\%) & $6 / 7(85.7 \%)$ & $7 / 7(100 \%)$ \\
\hline Clear cell foci & $1 / 7(14.3 \%)$ & $0 / 7(0)$ & $1 / 7(14.3 \%)$ \\
\hline
\end{tabular}

Data represent the proportion of affected animals (percentage) and were analyzed by Fisher's Exact Test $(\mathrm{p}<0.05)$.

${ }^{\text {a }}$ GZnA (adequate zinc, $35 \mathrm{mg} / \mathrm{kg}$ diet), GZnD (zinc deficiency, $3 \mathrm{mg} / \mathrm{kg}$ diet) or GZnS (zinc supplementation, $180 \mathrm{mg} / \mathrm{kg}$ diet) from postnatal day 28 until weeks 12 or 24. All groups were submitted to DEN/2-AAF treatment (see Material and Methods section). AHF $=$ Altered Hepatocyte Foci.

analysis showed typical membranous staining (Fig. 3A) in normalappearing liver areas and AHF in all mice from all experimental groups.
3.5. Zinc deficiency decreases GSH levels and increases peripheral blood and liver genotoxicity

Although zinc does not function as an antioxidant per se, this metal is essential for multiple enzymes participating in antioxidant defense (Kloubert and Rink, 2015). Dietary zinc deficiency decreased hepatic GSH levels when compared to adequate zinc diet and zinc deficiency at both moments (weeks 12 and 24) $(\mathrm{p}<0.001$, for both) (Table 3). Moreover, zinc deficiency increased 2-AAFinduced genotoxicity in both peripheral blood and liver cells when compared to the other groups at the late time-point (week 24) ( $\mathrm{p}=0.037$ and $\mathrm{p}=0.023$, respectively) (Fig. 4).

\subsection{Zinc supplementation increases antioxidant defense and decreases peripheral blood genotoxicity}

Dietary zinc supplementation increased hepatic GSH levels and GPx activity when compared to adequate zinc diet and zinc deficiency at week 12 ( $p<0.001$, for both) and week 24 ( $p<0.001$, for both) (Table 3). Zinc supplementation also increased total SOD and catalase activities in comparison to the other groups only at week 24 ( $\mathrm{p}<0.001$ and $\mathrm{p}=0.038$, respectively). In addition, zinc 

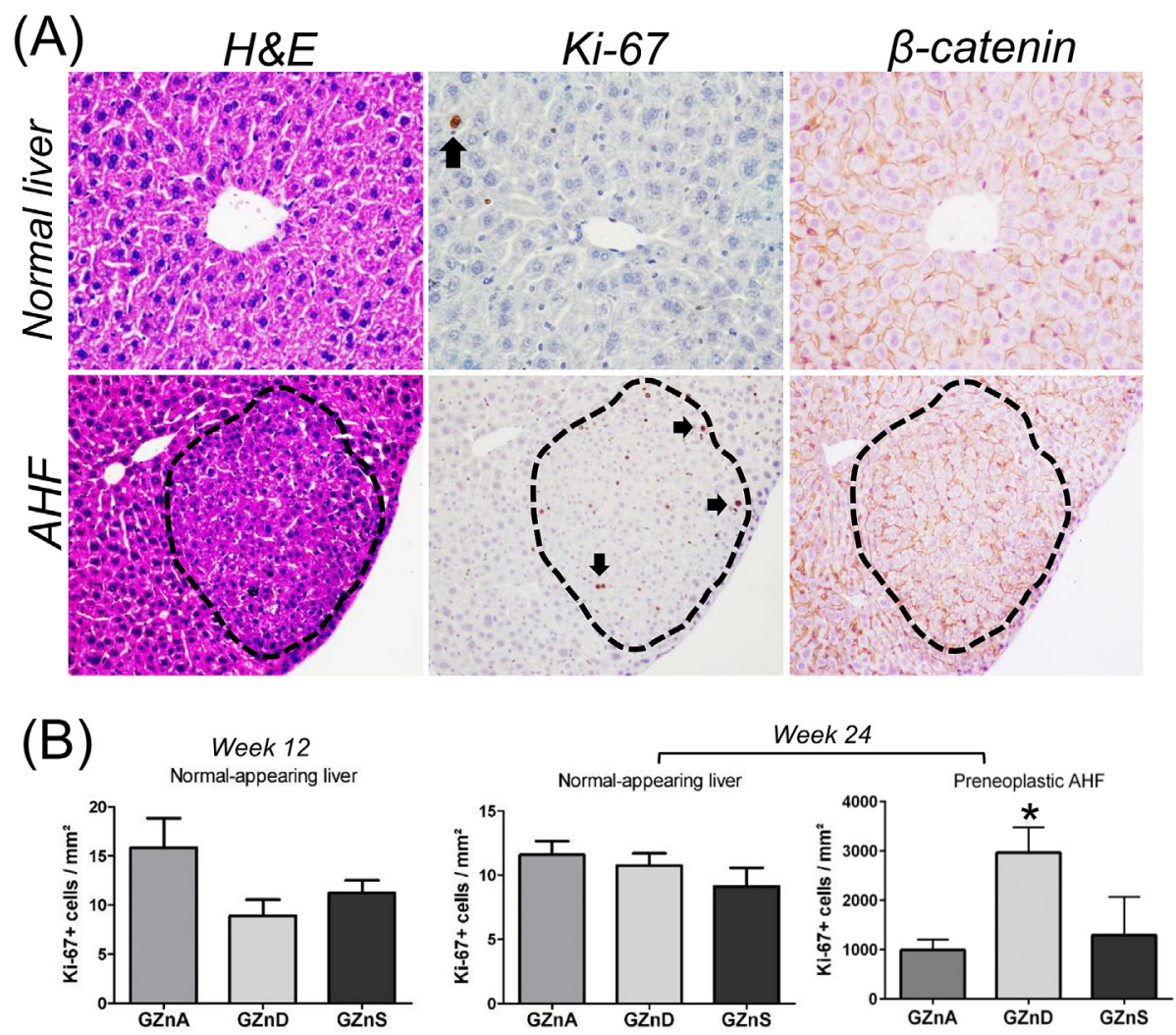

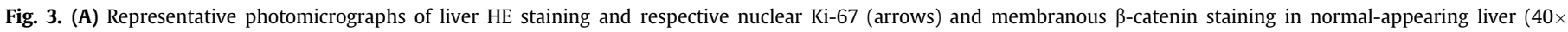

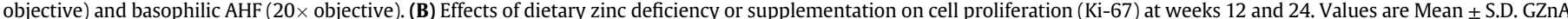




difference compared to the other groups by ANOVA post hoc Tukey's test: ${ }^{*} \mathrm{p}<0.05$.

Table 3

Effects of dietary zinc deficiency or supplementation on liver antioxidant profiling at weeks 12 and 24.

\begin{tabular}{llll}
\hline Week/Parameters & \multicolumn{2}{l}{ Groups $^{\mathrm{a}}$} & \\
\cline { 2 - 4 } & GZnA & GZnD & GZnS \\
\hline Week 12 ( $n=6$ mice/group) & & & \\
GSH (nmol/g tissue) & $8.03 \pm 0.72$ & $6.15 \pm 0.64^{* *}$ & $10.8 \pm 1.25^{* *}$ \\
SOD (nmol/mg protein) & $40.7 \pm 5.12$ & $42.4 \pm 6.01$ & $45.5 \pm 9.25$ \\
Catalase ( $\mu$ mol/g tissue) & $19.5 \pm 1.59$ & $17.6 \pm 2.77$ & $19.9 \pm 1.85$ \\
GPx (nmol/mg tissue) & $11.6 \pm 1.57$ & $10.7 \pm 1.48$ & $15.1 \pm 1.48^{* *}$ \\
Week 24 ( $n=7$ mice/group) & & & \\
GSH (nmol/g tissue) & $7.49 \pm 1.17$ & $5.22 \pm 0.68^{* *}$ & $8.86 \pm 0.52^{* *}$ \\
SOD (nmol/mg protein) & $41.9 \pm 5.86$ & $37.3 \pm 3.24$ & $51.5 \pm 7.26^{* *}$ \\
Catalase ( $\mu$ mol/g tissue) & $23.8 \pm 7.83$ & $23.4 \pm 10.5$ & $32.6 \pm 7.75^{*}$ \\
GPx (nmol/mg tissue) & $8.93 \pm 1.44$ & $10.6 \pm 1.09$ & $20.5 \pm 2.16^{* *}$ \\
\hline
\end{tabular}

Values are Mean \pm S.D.

a GZnA (adequate zinc, $35 \mathrm{mg} / \mathrm{kg}$ diet), GZnD (zinc deficiency, $3 \mathrm{mg} / \mathrm{kg}$ diet) or GZnS (zinc supplementation, $180 \mathrm{mg} / \mathrm{kg}$ diet) from postnatal day 28 until weeks 12 or 24. All mice were submitted to DEN/2-AAF treatment (see Material and Methods section). $\mathrm{GSH}=$ reduced glutathione; $\mathrm{SOD}=$ superoxide dismutase; $\mathrm{GPX}=$ glutathione peroxidase. Asterisks correspond to statistical difference compared to the other groups by ANOVA post hoc Tukey's test: ${ }^{*} \mathrm{p}<0.05$ ** $\mathrm{p}<0.001$.

supplementation reduced 2-AAF-induced genotoxicity in peripheral blood cells when compared to adequate zinc diet at week 12 $(\mathrm{p}=0.032)$ (Fig. 4).

\subsection{Zinc deficiency decreases Nrf2 and increases $p 53$ and $p 65$ protein expression}

Since alterations in p53, p65 and $\beta$-catenin pathways are frequently observed in both human and rodent chemically-induced hepatocarcinogenesis (Jenkins and Parry, 2000; Anna et al., 2003; Park et al., 2005; Hussain et al., 2007; Majumder et al., 2010; Luedde and Schwabe, 2011), we investigated the effects of zinc deficiency or supplementation on the protein expression of these markers. At the early time-point (week 12), dietary zinc deficiency increased hepatic NFKB (p65) and p53 protein expression when compared to zinc supplementation and adequate zinc diet ( $\mathrm{p}=0.007$ and $\mathrm{p}=0.002$, respectively) (Fig. 5). In contrast, dietary zinc supplementation decreased hepatic $\beta$-catenin protein expression when compared to adequate zinc diet $(p=0.033)$ (Fig. 5).

We also evaluated Nrf2 protein expression, since alterations in Keap1/Nrf2/ARE pathway are common during the early stages of DEN/2-AAF-induced rodent hepatocarcinogenesis (Zavattari et al., 2015). Dietary zinc deficiency decreased hepatic Nrf2 protein expression in comparison to adequate zinc diet $(\mathrm{p}=0.026)$ at the early time-point (week 12) (Fig. 5). Groups showed similar protein expression of these markers at the late time-point (week 24).

\section{Discussion}

The present study investigated the modifying effects of dietary zinc deficiency or supplementation on the development of PNL in chemically-induced mouse hepatocarcinogenesis. At the early time-point (12 weeks), zinc deficiency decreased Nrf2 protein expression and GSH levels while increased p65 and p53 protein expression and the number of preneoplastic AHF/liver area. At the late time-point (24 weeks), zinc deficiency also decreased GSH 



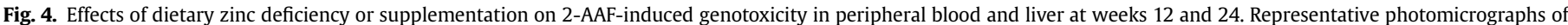



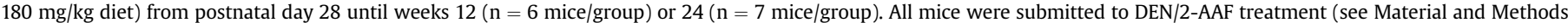
section). Asterisks correspond to statistical difference compared to GZnA or to all groups by ANOVA post hoc Tukey's test: *p < 0.05 .

levels while increased liver and peripheral blood genotoxicity, cell proliferation into AHF and AHF size.

As highlighted before, zinc has essential roles in antioxidant defense (Kloubert and Rink, 2015). Especially, the Keap1/Nrf2/ARE pathway is the main regulator of antioxidant/cytoprotective responses to endogenous and exogenous stresses caused by ROS and electrophiles (Nguyen et al., 2009). Under basal conditions, Keap1 dimer binds Nrf2 protein, leading it to proteasomal degradation (Nguyen et al., 2009). Under stressful conditions, Keap1 is inhibited, allowing Nrf2 protein to accumulate and to bind the antioxidant response element (ARE) (Nguyen et al., 2009). Finally, the Nrf2/ARE complex activates the expression of genes related to GSH synthesis, as glutamate-cysteine ligase (GCL) enzyme (Lu, 2013). GSH, a potent electron-donator, can directly interact with ROS and electrophiles, providing protection against electrophilic DNA-damaging agents (Ballatori et al., 2009), such as DEN and 2-AAF.

The Keap1/Nrf2/ARE pathway perceives stress partly by zinc signaling (McMahon et al., 2010). Stressful conditions increase intracellular free zinc $\left(\mathrm{Zn}^{2+}\right)$ levels by the oxidation and degradation of zinc-containing proteins (Kröncke, 2007). Keap1 holds domains that can act as "zinc sensors": enhanced intracellular zinc levels may act as negative regulators of Keap1, releasing and allowing Nrf2 to accumulate in cell (McMahon et al., 2010). In the present study, considering the importance of zinc on Keap1/Nrf2/ ARE pathway activation, dietary zinc deficiency decreased $\mathrm{Nrf} 2$ protein expression at week 12 . This decrease at the early time-point reduced GSH levels at both time-points (weeks 12 and 24) and, ultimately, contributed to enhance carcinogen (2-AAF)-induced oxidative stress and genotoxicity in the peripheral blood and especially in the liver at the late time-point (week 24) (Fig. 6). Similar findings were reported by recent in vitro studies (Omata et al., 2013; Li et al., 2014).

Zinc is also related to DNA repair since the DNA-binding domain of $\mathrm{p} 53$, a protein that coordinates proper DNA repair, exhibits a complex tertiary structure stabilized by zinc atoms (Loh, 2010; Méplan et al., 2000). Under hypoxia and/or oxidative stress, the p53 pathway is activated: p53 accumulates in the cell, leading to the expression of genes related to DNA repair, as GADD45 (Riley et al., 2008). In the present study, dietary zinc deficiency increased hepatic p53 protein expression at week 12 . In previous studies, zinc depletion also enhanced p53 protein expression in human lung fibroblasts and glioma cells. However, the p53 ability to bind target DNA sequences was reduced (Ho and Ames, 2002; Ho et al., 2003). Decreased intracellular zinc levels induce structural changes in p53 DNA-binding domain, impairing p53 DNA-binding capacity and proper DNA repair (Méplan et al., 2000; Verhaegh et al., 1998). Although we observed an increase in p53 expression at the early time-point, possibly as a result of enhanced carcinogeninduced oxidative stress caused by zinc deficiency, this protein may be structurally changed, and hence DNA repair is impaired. Thus, dietary zinc deficiency may not only impair antioxidant mechanisms as Nrf2/GSH, but also DNA repair mechanisms mediated by p53. As a consequence, these early alterations (week 12) may have contributed to augment carcinogen (2-AAF) induced-DNA damage at the late time-point (week 24) (Fig. 6).

In the early stage of chemically-induced hepatocarcinogenesis, the drastically modified hepatic environment of increased oxidative stress and DNA damage favors the emerging of preneoplastic AHF, possibly from the clonal expansion of initiated hepatocytes (Ogawa, 2009). Under stimuli, these lesions accumulate several molecular alterations and acquire phenotypic characteristics as genomic instability and high cell proliferation, which contribute to 
(A)
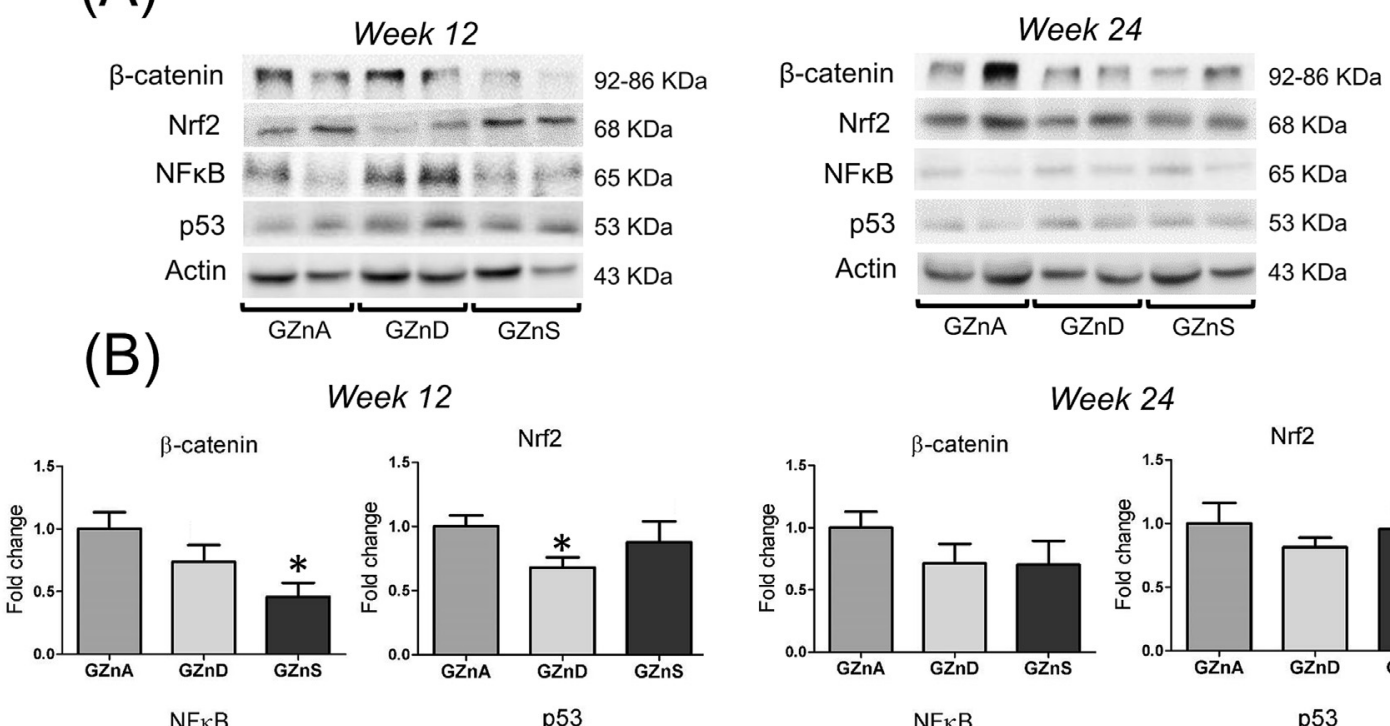

Week 24
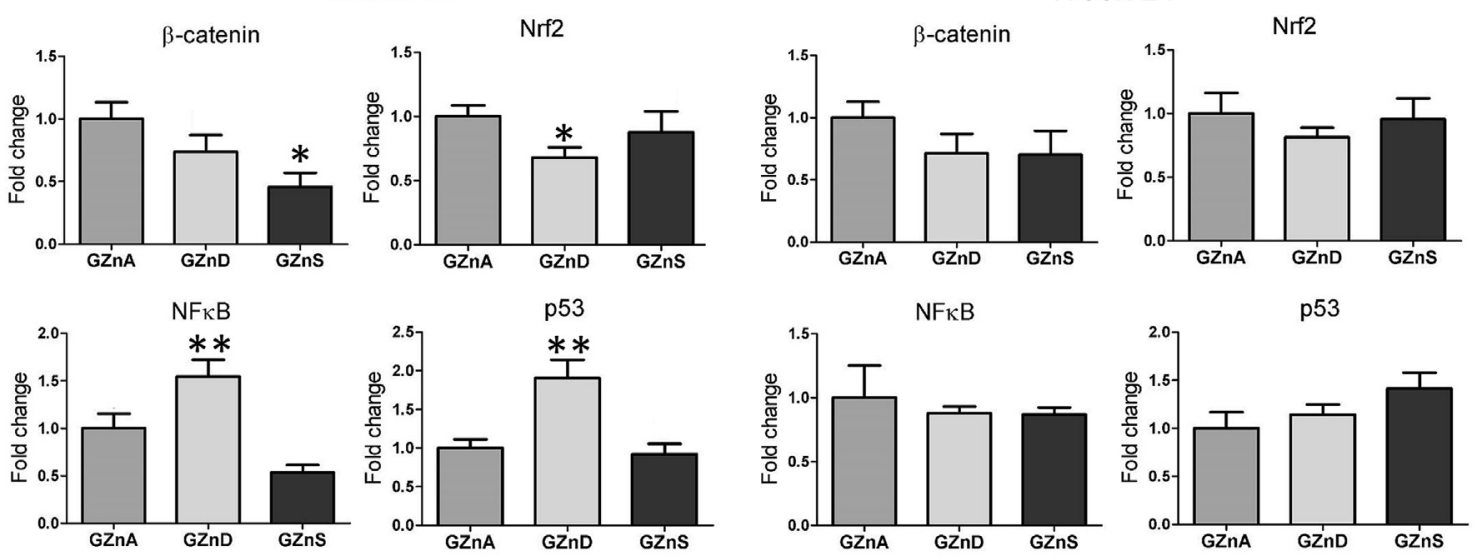

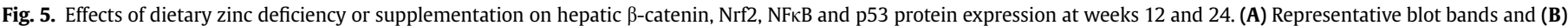

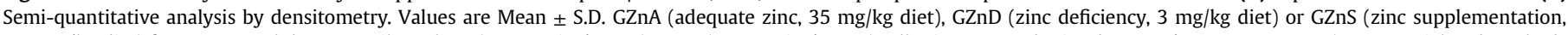


section). Asterisks correspond to statistical difference compared to GZnA or to all groups by ANOVA post hoc Tukey's test: *p < 0.05 ; **p $<0.01$.

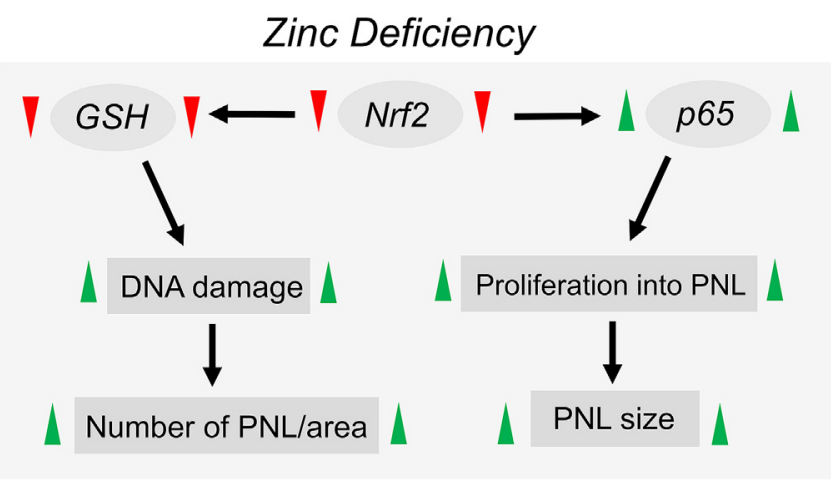

Fig. 6. Schematics of the predisposing effects of zinc deficiency on the development of hepatocellular preneoplastic lesions (PNL). The decrease of $\mathrm{Nrf} / \mathrm{GSH}$ pathway and increase of liver genotoxicity, as well as the increase of p65/cell proliferation, are potential mechanisms to this zinc deficiency-mediated effect. GSH = reduced glutathione; $\boldsymbol{\Lambda}$ = increase; $\mathbf{v}=$ decrease.

AHF development and ultimately, to AHF progression to adenomas and HCC (Ogawa, 2009). In the present study, the hepatic environment of defective antioxidant defense (Nrf2/GSH), DNA repair (p53) and enhanced DNA damage provided by zinc deficiency contributed to PNL development, resulting in enhanced number of AHF per liver area at week 12 (Fig. 6).

The nuclear factor $\kappa \mathrm{B}(\mathrm{NF} \kappa \mathrm{B})$ is a redox-sensitive transcription factor present in the cytoplasm as an inactive heterotrimer ( $\mathrm{p} 50$, p65, and IkB subunits) (Morgan and Liu, 2011). Under oxidative stress and other stimuli, IkB is phosphorylated by IкB quinase (IKK $\beta$ ), leading to nuclear translocation of p50 and p65 subunits and enhanced expression of genes involved in cell proliferation (as COX-2 and cyclin D1) (Morgan and Liu, 2011). Additionally, studies already reported a crosstalk between Nrf2 and NFKB pathways, usually inversely correlated: when Nrf2 pathway is activated, Keap1 acts as a negative regulator of NFKB signaling through the inhibition and degradation of IKK $\beta$ (Kim et al., 2010; Lee et al., 2009).

Therefore, the reduction of Nrf2 protein expression mediated by zinc deficiency at the early time-point (week 12) has provided the stimulus for NFKB pathway activation at the same time-point. When activated, the NFKB (p65) transcription factor augmented the cell proliferation into preneoplastic AHF and, as a result, AHF size at the late time-point (week 24) (Fig. 6). In agreement, Majumder et al. (2010) observed that zinc-dependent metallothionein knockout induced oxidative stress, NFKB pathway activation, followed by an increase in cell proliferation and in the incidence of hepatocellular adenoma/carcinoma in a DEN-induced mouse hepatocarcinogenesis. Increased cell proliferation into AHF benefits the clonal expansion of DEN/2-AAF initiated hepatocytes and favors the accumulation of molecular alterations that predispose to AHF growth and progression to tumors (Ogawa, 2009). Then, the increases in the number of AHF per liver area, AHF cell proliferation and, consequently, AHF size may be considered direct predisposing effects of zinc deficiency on chemically-induced hepatocarcinogenesis.

In contrast, dietary zinc supplementation enhanced total SOD and catalase activities at week 24 and increased hepatic GPx activity and GSH levels at both time-points. Zinc is an essential structural component of copper and zinc-dependent superoxide dismutase enzyme (CuZnSOD) (Zelko et al., 2002). Also, zinc atoms are part of zinc finger proteins responsible for DNA-binding activity 
of Sp1 transcription factor which induces the expression of catalase, another important antioxidant enzyme (Lee et al., 2005). Thus, increased levels or activity of these antioxidant agents may have protected peripheral blood cells against ROS and nucleophilic ions produced by DEN/2-AAF metabolism, resulting in decreased DNA damage at week 12 .

Although zinc supplementation (drinking water, $75 \mathrm{mg} / \mathrm{L}$ ) already showed to attenuate mouse alcoholic hepatic injury by inhibiting the generation of ROS and enhancing antioxidant pathways (Zhou et al., 2005), dietary zinc supplementation used herein did not alter the incidence or the number of preneoplastic AHF per liver area, as well as AHF size and cell proliferation. On the other hand, zinc supplementation reduced $\beta$-catenin protein expression at the early time-point (week 12). The $\mathrm{Wnt} / \beta$-catenin pathway plays important roles in liver growth, regeneration and proliferation (Micsenyi et al., 2004; Tan et al., 2006). In contrast, Wnt $/ \beta$ catenin pathway aberrant activation, as a result of mutations in $\beta$ catenin gene, is frequently found in human and chemically-induced HCC, including DEN-induced models (Anna et al., 2003; Park et al., 2005). Therefore, it is hypothesized that increased antioxidant defense as well as decreased $\beta$-catenin protein expression could provide a hepatoprotective environment against late HCC development. However, further long-term studies are necessary.

Taken together, our findings demonstrate that dietary zinc deficiency predisposes mice to the development of PNL in chemically-induced hepatocarcinogenesis. The decrease of Nrf2/ GSH pathway and subsequent increase of liver genotoxicity, as well as the increase of p65/cell proliferation, are proposed as potential mechanisms to this zinc deficiency-mediated effect (Fig. 6). Our findings could also indicate an underlying role of this nutritional imbalance as a risk cofactor of human hepatocarcinogenesis. To our knowledge, this is the first report of the predisposing effects of dietary zinc deficiency on a classical and well-established hepatocarcinogenesis model. In contrast, despite of conferring a hepatoprotective environment by enhancing antioxidant defense, dietary zinc supplementation does not protect mice against the development of PNL in chemically-induced hepatocarcinogenesis.

\section{Acknowledgements}

We thank Paulo César Georgete and Corina Julieta Correa Tomasetti for the technical support during the experimental period. Guilherme R. Romualdo was recipient of a fellowship and grants from FAPESP (2014/01795-0). Luis F. Barbisan was recipient of support research from FAPESP (2012/13004-1).

\section{Transparency document}

Transparency document related to this article can be found online at http://dx.doi.org/10.1016/j.fct.2016.08.020.

\section{References}

Alder, H., Taccioli, C., Chen, H., Jiang, Y., Smalley, K.J., Fadda, P., Ozer, H.G., Huebner, K., Farber, J.L., Croce, C.M., Fong, L.Y.Y., 2012. Dysregulation of miR-31 and miR-21 induced by zinc deficiency promotes esophageal cancer. Carcinogenesis 33, 1736-1744.

Andreini, C., Banci, L., Bertini, I., Rosato, A., 2006. Zinc through the three domains of life. J. Proteome Res. 5, 3173-3178.

Anna, C.H., Iida, M., Sills, R.C., Devereux, T.R., 2003. Expression of potential $\beta$-catenin targets, cyclin D1, c-Jun, c-Myc, E-cadherin, and EGFR in chemically induced hepatocellular neoplasms from B6C3F1 mice. Toxicol. Appl. Pharmacol. 190, 135-145.

Bakiri, L., Wagner, E.F., 2013. Mouse models for liver cancer. Mol. Oncol. 7, 206-223.

Ballatori, N., Krance, S.M., Notenboom, S., Shi, S., Tieu, K., Hammond, C.L., 2009. Glutathione dysregulation and the etiology and progression of human diseases. Biol. Chem. 390, 191-214.

Banudevi, S., Elumalai, P., Arunkumar, R., Senthilkumar, K., Gunadharini, D.N.,
Sharmila, G., Arunakaran, J., 2011. Chemopreventive effects of zinc on prostate carcinogenesis induced by $\mathrm{N}$-methyl-N-nitrosourea and testosterone in adult male Sprague-Dawley rats. J. Cancer Res. Clin. Oncol. 137, 677-686.

Bergmeyer, H.U., 1974. Methods of Enzymatic Analysis, second ed. Academic Press, New York.

Bitsch, A., Hadjiolov, N., Klo, P., Bergmann, O., Zwirner-baier, I., 2000. Dose response of early effects related to tumor promotion of 2-Acetylaminofluorene. Toxicol. Sci. 51, 44-51.

Brooks, W.A., Santosham, M., Naheed, A., Goswami, D., Wahed, M.A., DienerWest, M., Faruque, A.S., Black, R.E., 2005. Effect of weekly zinc supplements on incidence of pneumonia and diarrhoea in children younger than 2 years in an urban, low-income population in Bangladesh: randomised controlled trial. Lancet 366, 999-1004.

Christudoss, P., Selvakumar, R., Pulimood, A.B., Fleming, J.J., Mathew, G., 2012. Zinc and zinc related enzymes in precancerous and cancerous tissue in the colon of dimethyl hydrazine treated rats. Asian Pac. J. Cancer Prev. 13, 487-492.

Dani, V., Goel, A., Vaiphei, K., Dhawan, D.K., 2007. Chemopreventive potential of zinc in experimentally induced colon carcinogenesis. Toxicol. Lett. 171, 10-18.

Ewing, J.F., Janero, D.R., 1995. Microplate superoxide dismutase assay employing a nonenzymatic superoxide generator. Anal. Biochem. 232, 243-248.

Fong, L.Y.Y., Jiang, Y., Farber, J.L., 2006. Zinc deficiency potentiates induction and progression of lingual and esophageal tumors in p53-deficient mice. Carcinogenesis 27, 1489-1496.

Fong, L.Y.Y., Jiang, Y., Rawahneh, M.L., Smalley, K.J., Croce, C.M., Farber, J.L., Huebner, K., 2011. Zinc supplementation suppresses 4-nitroquinoline 1-oxideinduced rat oral carcinogenesis. Carcinogenesis 32, 554-560.

Food and Nutrition Board, 2001. Dietary Reference Intakes for Vitamin A, Vitamin K, Arsenic, Boron, Chromium, Copper, Iodine, Iron, Manganese, Molybdenum, Nickel, Silicon, Vanadium, and Zinc. The National Academic Press, Washington.

GLOBOCAN, 2012. GLOBOCAN 2012: Estimated cancer Incidence, Mortality and Prevalence Worldwide in 2012. http://globocan.iarc.fr/Default.aspx (accessed 01.09.15.).

Gumulec, J., Masarik, M., Adam, V., Eckschlager, T., Provaznik, I., Kizek, R., 2014. Serum and tissue zinc in epithelial malignancies: a meta-analysis. PLoS One 9, e99790.

Ho, E., Ames, B.N., 2002. Low intracellular zinc induces oxidative DNA damage, disrupts p53, NFkappa B, and AP1 DNA binding, and affects DNA repair in a rat glioma cell line. Proc. Natl. Acad. Sci. U. S. A. 99, 16770-16775.

Ho, E., Courtemanche, C., Ames, B.N., 2003. Zinc deficiency induces oxidative DNA damage and increases p53 expression in human lung fibroblasts. J. Nutr. 133, 2543-2548.

Huang, L., Yu, Y.Y., Kirschke, C.P., Gertz, E.R., Lloyd, K.K.C., 2007. Znt7 (Slc30a7)deficient mice display reduced body zinc status and body fat accumulation. J. Biol. Chem. 282, 37053-37063.

Hussain, S.P., Schwank, J., Staib, F., Wang, X.W., Harris, C.C., 2007. TP53 mutations and hepatocellular carcinoma: insights into the etiology and pathogenesis of liver cancer. Oncogene 26, 2166-2176.

Jenkins, G.J., Parry, J.M., 2000. Restriction site mutation (RSM) analysis of 2 acetylaminofluorene (2-AAF)-induced mouse liver mutations and comparison with the measurement of in vivo micronucleus induction in the bone marrows of (2-AAF)-treated mice. Teratog. Carcinog. Mutagen 20, 107-117.

Jin, S.K., Wanibuchi, H., Morimura, K., Gonzalez, F.J., Fukushima, S., 2007. Role of CYP2E1 in diethylnitrosamine-induced hepatocarcinogenesis in vivo. Cancer Res. 67, 11141-11146.

Jing, M., Rech, L., Wu, Y., Goltz, D., Taylor, C.G., House, J.D., 2015. Effects of zinc deficiency and zinc supplementation on homocysteine levels and related enzyme expression in rats. J. Trace Elem. Med. Biol. 30, 77-82.

Kim, J.E., You, D.J., Lee, C., Ahn, C., Seong, J.Y., Hwang, J.I., 2010. Suppression of NF-кB signaling by KEAP1 regulation of IKK $\beta$ activity through autophagic degradation and inhibition of phosphorylation. Cell. Signal. 22, 1645-1654.

Klaunig, J.E., Pereira, M.A., Ruch, R.J., Weghorst, C.M., 1988. Dose-response relationship of diethylnitrosamine-initiated tumors in neonatal balb/c mice: effect of phenobarbital promotion. Toxicol. Pathol. 16, 381-385.

Kloubert, V., Rink, L., 2015. Zinc as a micronutrient and its preventive role of oxidative damage in cells. Food Funct. 6 (10), 3195-3204.

Ko, W.S., Guo, C.H., Hsu, G.S., Chiou, Y.L., Yeh, M.S., Yaun, S.R., 2005. The effect of zinc supplementation on the treatment of chronic hepatitis $C$ patients with interferon and ribavirin. Clin. Biochem. 38, 614-620.

Kraynak, A.R., Barnum, J.E., Cunningham, C.L., Ng, A., Ykoruk, B.A., Bennet, B. Stoffregen, D., Merschman, M., Freeland, E., Galloway, S.M., 2015. Alkaline comet assay in liver and stomach, and micronucleus assay in bone marrow, from rats treated with 2-acetylaminofluorene, azidothymidine, cisplatin, or isobutyraldehyde. Mutat. Res. 786-788, 77-86.

Kröncke, K.D., 2007. Cellular stress and intracellular zinc dyshomeostasis. Arch. Biochem. Biophys. 463, 183-187.

Kumaravel, T.S., Jha, A.N., 2006. Reliable Comet assay measurements for detecting DNA damage induced by ionising radiation and chemicals. Mutat. Res. 605, 7-16.

Lee, D.F., Kuo, H.P., Liu, M., Chou, C.K., Xia, W., Du, Y., Shen, J., Chen, C.T., Huo, L., Hsu, M.C., Li, C.W., Ding, Q., Liao, T.L., Lai, C.C., Lin, A.C., Chang, Y.H., Tsai, S.F. Li, L.Y., Hung, M.C., 2009. KEAP1 E3 ligase-mediated downregulation of NFkappaB signaling by targeting IKKbeta. Mol. Cell 36, 131-140.

Lee, J.A., Suh, D.C., Kang, J.E., Kim, M.H., Park, H., Lee, M.N., Kim, J.M., Jeon, B.N., Roh, H.E., Yu, M.Y., Choi, K.Y., Kim, K.Y., Hur, M.W., 2005. Transcriptional activity of $\mathrm{Sp} 1$ is regulated by molecular interactions between the zinc finger DNA 
binding domain and the inhibitory domain with corepressors, and this interaction is modulated by MEK. J. Biol. Chem. 280, 28061-28071.

Lee, S., Simpson, M., Nimmo, M., Xu, Z., 2004. Low zinc intake suppressed N-methyl$\mathrm{N}$-nitrosourea-induced mammary tumorigenesis in Spraque-Dawley rats. Carcinogenesis 25, 1879-1885.

Li, B., Cui, W., Tan, Y., Luo, P., Chen, Q., Zhang, C., Qu, W., Miao, L., Cai, L., 2014. Zinc is essential for the transcription function of Nrf2 in human renal tubule cells in vitro and mouse kidney in vivo under the diabetic condition. J. Cell. Mol. Med. 18, 895-906.

Liu, L.L., Gong, L.K., Qi, X.M., Cai, Y., Wang, H., Wu, X.F., Xiao, Y., Ren, J., 2005. Altered expression of cytochrome P450 and possible correlation with preneoplastic changes in early stage of rat hepatocarcinogenesis. Acta Pharmacol. Sin. 26, $737-744$.

Loh, S.N., 2010. The missing zinc: p53 misfolding and cancer. Metallomics 2, $442-449$.

Lu, S.C., 2013. Glutathione synthesis. Biochim. Biophys. Acta 1830, 3143-3153.

Luedde, T., Schwabe, R.F., 2011. NF-кB in the liver-linking injury, fibrosis and hepatocellular carcinoma. Nat. Rev. Gastroenterol. Hepatol. 8, 108-118.

Ma, J., Betts, N.M., 2000. Zinc and copper intakes and their major food sources for older adults in the 1994-96 continuing survey of food intakes by individuals (CSFII). J. Nutr. 130, 2838-2843.

Majumder, S., Roy, S., Kaffenberger, T., Wang, B., Costinean, S., Frankel, W. Bratasz, A., Kuppusamy, P., Hai, T., Ghoshal, K., Jacob, S.T., 2010. Loss of metallothionein predisposes mice to diethylnitrosamine-induced hepatocarcino-



Margalit, O., Simon, A.J., Yakubov, E., Puca, R., Yosepovich, A., Avivi, C., JacobHirsch, J., Gelernter, I., Harmelin, A., Barshack, I., Rechavi, G., D'Orazi, G. Givol, D., Amariglio, N., 2012. Zinc supplementation augments in vivo antitumor effect of chemotherapy by restoring p53 function. Int. J. Cancer 131, E562-E568.

McMahon, M. Lamont, D.J. Beattie, K.A., Hayes, J.D., 2010. Keap1 perceives stres via three sensors for the endogenous signaling molecules nitric oxide, zinc, and alkenals. PNAS 107, 18838-18843.

Méplan, C., Richard, M.J., Hainaut, P., 2000. Metalloregulation of the tumor suppressor protein p53: zinc mediates the renaturation of $\mathrm{p} 53$ after exposure to metal chelators in vitro and in intact cells. Oncogene 19, 5227-5236.

Micsenyi, A., Tan, X., Sneddon, T., Luo, J.-H., Michalopoulos, G.K., Monga, S.P.S., 2004 $\beta$-Catenin is temporally regulated during normal liver development. Gastroenterol 126, 1134-1146.

Morgan, M.J., Liu, Z., 2011. Crosstalk of reactive oxygen species and NF-кB signaling. Cell Res. 21, 103-115.

Nakamura, W., Hojoda, S., Hayashi, K., 1974. Purification and properties of rat liver glutathione peroxidase. Biochim. Biophys. Acta 358, 251-261.

National Research Council (US) Committee for the Update of the Guide for the Care and Use of Laboratory Animals, 2011. Guide for the Care and Use of Laboratory Animals, eight ed. National Academies Press, Washington (DC).

National Academy of Sciences (US), 2001. Subcommittee on Laboratory Animal Nutrition: Dietary Reference Intakes for Vitamin A, Vitamin K, Arsenic, Boron, Chromium, Copper, Iodine, Iron, Manganese, Molybdenum, Nickel, Silicon, Vanadium, and Zinc. National Academy Press, Washington (DC).

Nguyen, T., Nioi, P., Pickett, C.B., 2009. The Nrf2-antioxidant response element signaling pathway and its activation by oxidative stress. J. Biol. Chem. 284, 13291-13295.

Ogawa, K., 2009. Molecular pathology of early stage chemically induced hepatocarcinogenesis. Pathol. Int. 59, 605-622.

Omata, Y., Salvador, G.A., Supasai, S., Keenan, A.H., Oteiza, P.I., 2013. Decreased zinc availability affects glutathione metabolism in neuronal cells and in the developing brain. Toxicol. Sci. 133, 90-100.

Palmeira, S.M., Silva, P.R.P., Ferrão, J.S.P., Ladd, A.A.B.L., Dagli, M.L.Z., Grisolia, C.K. Hernandez-Blazquez, F.J., 2015. Chemopreventive effects of pequi oil (Caryocar brasiliense Camb.) on preneoplastic lesions in a mouse model of hepatocarcinogenesis. Eur. J. Cancer Prev. 25 (4), 299-305.

Park, H.J., Oh, J.H., Park, S.M., Cho, J.W., Yum, Y.N., Park, S.N., Yoon, D.Y., Yoon, S., 2011. Identification of biomarkers of chemically induced hepatocarcinogenesis in rasH2 mice by toxicogenomic analysis. Arch. Toxicol. 85, 1627-1640.

Park, J.Y., Park, W.S., Nam, S.W., Kim, S.Y., Lee, S.H., Yoo, N.J. Lee, J.Y., Park, C.K., 2005. Mutations of beta-catenin and AXIN I genes are a late event in human hepatocellular carcinogenesis. Liver Int. 25, 70-76.

Pitot, H.C., 1990. Altered hepatic foci: their role in murine hepatocarcinogenesis Annu. Rev. Pharmacol. Toxicol. 30, 465-500.
Reeves, P.G., Nielsen, F.H., Fahey, G.C., 1993. AIN-93 purified diets for laboratory rodents: final report of the American Institute of Nutrition ad hoc writing committee on the reformulation of the AIN-76A rodent diet. J. Nutr. 123, 1939-1951.

Riley, T., Sontag, E., Chen, P., Levine, A., 2008. Transcriptional control of human p53regulated genes. Nat. Rev. Mol. Cell Biol. 9, 402-412.

Roohani, N., Hurrell, R., Kelishadi, R., Schulin, R., 2013. Zinc and its importance for human health: an integrative review. J. Res. Med. Sci. 18, 144-157.

Santos, N.P., Colaç, A., da Costa, R.M.G., Oliveira, M.M., Peixoto, F., Oliveira, P.A., 2014. N-diethylnitrosamine mouse hepatotoxicity: time-related effects on histology and oxidative stress. Exp. Toxicol. Pathol. 66, 429-436.

Sanyal, A.J., Yoon, S.K., Lencioni, R., 2010. The etiology of hepatocellular carcinoma and consequences for treatment. Oncologist 15 (Suppl. 4), 14-22.

Sedlak, J., Lindsay, R.H., 1968. Estimation of total protein bound and nonprotein sulfydryl groups in tissue with Ellman's reagent. Anal. Biochem. 25, 192-205.

Song, Y., Leonard, S.W., Traber, M.G., Ho, E., 2009. Zinc deficiency affects DNA damage, oxidative stress, antioxidant defenses, and DNA repair. J. Nutr. 139, 1626-1631.

Sun, J., Liu, J., Pan, X., Quimby, D., Zanesi, N., Druck, T., Pfeifer, G.P., Croce, C.M., Fong, L.Y., Huebner, K., 2011. Effect of zinc supplementation on N-nitrosomethylbenzylamine-induced forestomach tumor development and progression in tumor suppressor-deficient mouse strains. Carcinogenesis 32, 351-358.

Taccioli, C., Chen, H., Jiang, Y., Liu, X.P., Huang, K., Smalley, K.J., Farber, J.L., Croce, C.M., Fong, L.Y., 2012. Dietary zinc deficiency fuels esophageal cancer development by inducing a distinct inflammatory signature. Oncogene 31, $4550-4558$

Tan, X., Behari, J., Cieply, B., Michalopoulos, G.K., Monga, S.P.S., 2006. Conditional deletion of $\beta$-catenin reveals its role in liver growth and regeneration. Gastroenterol 131, 1561-1572.

Thoolen, B., Maronpot, R.R., Harada, T., Nyska, A., Rousseaux, C., Nolte, T., Malarkey, D.E., Kaufmann, W., Küttler, K., Deschl, U., Nakae, D., Gregson, R., Vinlove, M.P., Brix, A.E., Singh, B., Belpoggi, F., Ward, J.M., 2010. Proliferative and nonproliferative lesions of the rat and mouse hepatobiliary system. Toxicol. Pathol. 38, 5S-81S.

Tice, R.R., Agurell, E., Anderson, D., Burlinson, B., Hartmann, A., Kobayashi, H., Miyamae, Y., Rojas, E., Ryu, J.C., Sasaki, Y.F., 2000. Single cell gel/comet assay: guidelines for in vitro and in vivo genetic toxicology testing. Environ. Mol. Mutagen 35, 206-221.

Verhaegh, G.W., Parat, M.O., Richard, M.J., Hainaut, P., 1998. Modulation of p53 protein conformation and DNA-binding activity by intracellular chelation of zinc. Mol. Carcinog. 21, 205-214.

Vesselinovitch, S.D., 1987. Certain aspects of hepatocarcinogenesis in the infant mouse model. Toxicol. Pathol. 15, 221-228.

Vesselinovitch, S.D., Koka, M., Mihailovich, N., Rao, K.V., 1984. Carcinogenicity of diethylnitrosamine in newborn, infant, and adult mice. J. Cancer Res. Clin. Oncol. 108, 60-65.

Wessells, K.R., Brown, K.H., 2012. Estimating the global prevalence of zinc deficiency: results based on zinc availability in national food supplies and the prevalence of stunting. PLoS One 7, e50568.

Yakoob, M.Y., Theodoratou, E., Jabeen, A., Imdad, A., Eisele, T.P., Ferguson, J., Jhass, A., Rudan, I., Campbell, H., Black, R.E., Bhutta, Z.A., 2011. Preventive zinc supplementation in developing countries: impact on mortality and morbidity due to diarrhea, pneumonia and malaria. BMC Public Health 11, S23.

Zavattari, P., Perra, A., Menegon, S., Kowalik, M.A., Petrelli, A., Angioni, M.M., Follenzi, A., Quagliata, L., Ledda-Columbano, G.M., Terracciano, L., Giordano, S. Columbano, A., 2015. Nrf2, but not $\beta$-catenin, mutation represents an early event in rat hepatocarcinogenesis. Hepatology 62, 851-862.

Zelko, I.N., Mariani, T.J., Folz, R.J., 2002. Superoxide dismutase multigene family: a comparison of the CuZn-SOD (SOD1), Mn-SOD (SOD2), and EC-SOD (SOD3) gene structures, evolution, and expression. Free Rad. Biol. Med. 33, 337-349.

Zhong, W., Zhao, Y., Sun, X., Song, Z., McClain, C.J., Zhou, Z., 2013. Dietary zinc deficiency exaggerates ethanol-induced liver injury in mice: involvement of intrahepatic and extrahepatic factors. PloS One 8, e76522.

Zhou, Z., Wang, L., Song, Z., Saari, J.T., McClain, C.J., Kang, Y.J., 2005. Zinc supplementation prevents alcoholic liver injury in mice through attenuation of oxidative stress. Am. J. Pathol. 166, 1681-1690.

Zucman-Rossi, J., 2008. Human and mouse hepatocellular adenoma and carcinoma display similar tumorigenesis pathway alterations. J. Hepatol. 48, 884-886. 